16) Heribert Schatz: "Ein theoretischer Bezugsrahmen für das Verhälnis von Politik und Massenkommunikation" ${ }^{*}$ In: Wolfgang R. Langenbucher ( $\left.\mathrm{Hg}_{*}\right)$ Politik und Kommunikation. München 1979.

17) F1. Arentoft (red.): Provins - et politisk problem. Århus 1977.

D. Bellmann, W. Hein, W. Trapp, G. Zang: "Provins som et politisk problem". In: Provins - et politisk problem, op cit.

18) Albrecht Funk, Hatmut Häussermann, Hans-Dieter Will: "Staatsapparat und regionalpolitik". In: Rolf Ebbighausen (red.): Bürgerlicher Staat und politische Legitimation. Frankfurt a.M. 1975. S5. 281-308.

19) Betankning 592 1979, s. 31. Cit. fra Jette Tybjerg op. cit. s. 56

20) Folketingstidende $1975 / 76$, sp. 8259 . Cit. fra Jette Tybjerg op. cit. s. 122.

21) Folketingstidende $1967 / 68$, sp. 2325. Cit. fra Jette Tybjerg op. cit. 5.53 , min understregning.

22) Folketingstidende 1973/74, sp. 4281. Cit. fra Jette Tybjerg op. cit. s. 117.

23) Dette afsnit bygger p\$ f $\$$ lgende arbejder:

Blanke, Jürgens, Kastendiek: Kritik der politischen Wisenchaft 1.-2. Frankfurt a.M. 1975

Luhmann: Legitimation durch Vertahren. Neuwied 1969.

Habermas/Luhmann: Theorie der Gesellschaft oder Sozialtechnologie. Frankfurt a.M. 1971 .

Habermas: Legitimationsproblemer I senkapitalismen. Kbh. 1973

Frieder Naschold: Organisation und Demókratie. Stuttgart 1969.

Claus Offe: Strukturprobleme des kapitalistischen Staates. Aufsätze zur politischen Soziologie. Frankfurt a.M. 1972. 


\title{
FÖRENINGSRADIO PÅ FÖRSÖK I SVERIGE
}

\author{
av Lowe Hedman
}

\section{BAKGRUND}

Samtlige statliga radioutredningar som ägt rum i Syerige har diskuterat hur folkrörelsers och olika organisationers intressen skulle kunna tillvaratas och hur behovet av utbildning och undervisning skulle kunna tillgodoses inom de etablerade etermedierna. 1960 års radioutredning gjorde detta under beteckningen "särskild rundradio" Med detta begrepp avsågs alla de mer specialiserade verksamheter som inte rymdes inom Sveriges Radios ram.

1960 ars utredning, som lämnade sitt betänkande 1965 (SOU 1965:20), föreslog bla. att ett antal sändningsmöjligheter som Sveriges Radio inte behövde skulle utnyttjas för "särskild rundradio" och att Sveriges Radios regionala sändningar skulle utökas väsentligt. Om särskilda behov förelag kunde man även tänka sig "subregionala" sändningar. Aven om dessa förslag i väsentliga avseenden avviker från den närradiomodell som senare kom att praktiseras i Sverige har de dock haft betydelse för denna.

Det var i själva verket en teknisk innovation, nämligen ett stereosystem där man hade möjlighet att klyva FM-kanalerna i tva och samtidigt lösa problemen med den överhörning som uppstod mellan kanalerna, som gav upphov till idén med särskild rundradio. Av de ursprungliga tre FM-kanalema skulle man kunna behalla en för stereofoniska sändningar och dela de två övriga så att man dessutom fick kanaler för mono-sändningar. Enligt utredningens förslag skulle en eller två av de nya kanalerna ställas till olika organisationers och myndigheters förfogande och da utan de krav på opartiskhet och saklighet som finns I den radiolag som reglerar Skeriges Radios programverksamhet. Sändningama pa de nya kanalerna skulle gå ut över hela landet, eftersom de kunde antas ha intresse för människor i alla delar av landet. Det bör framhallas att de tekniska förutsättningarna för de två extra kanalerna numera är borta, eftersom. Sverige nu valt det stereosystem som används i de flesta andra länder och där möjligheterna att sända två olika program per kanal saknas (SOU 1965:20, sid 118).

Kostnaderna för den särskilda rundradions sändningar skulle bestridas av de deltagande organisationerna och myndigheterna. För att fördela tiden mellan de 
olika intressenterna skulle en särskild "sändningsnämnd" bildas. Denna nämnd skulle ocksa kunna dela ut varningar och dra in sändningstillstånd, om någon sändande institution bröt mot de regler som skulle gälla för verksamheten. En regel skulle vara att kommersiell reklam inte fick förekomma.

De flesta remissinstanser som lick möjlihet att yttra sig över utredningens förslag ställde sig positiva till det. Från många håll framhöls dock att ytterligare undersökningar var nödvåndiga. Hos den dåvarande socialdemokratiska regeringen fick utredningens förslag inget gehör och det ansvariga statsrådet menade att förslaget var alltiör skissartat för att ligga till grund för ett beslut I frågan (Proposition 1966: 136, sid 130 1). Man kan konstatera att förslaget om särskild rundradio redan vid den tidspunkten var en politisk fråga som kom att företrädas främst av den folkpartistiske ledamoten av radioutredningen och av han partis.

Den p\& utredningen följande propositionen gick inte heller p\& den föreslagna linjen vad beträffar utbyggnaden av de enskilda distrikten. Redan 1960 förekom dock regional ljudradioproduktion i hela Sverige efter en relativt snabb utbyggnad under perioden efter andra världskriget. Den regionale programproduktionen åndrade nu successivt inriktning. Från att från början huvudsakligen ha varit inriktad på att täcka det behov av material från andra landsändar än huvudstaden som artikulerades fran huvudkontorets sida, kom produktionen mer och mer att inriktas pa regionala utsändningar. Bearbetningar av tillgänglig statistik visar at andelen regionala sãndningar av distriktskontorens produktion ökade från $17 \%$ ăr 1959/60 till $45 \% 1963 / 64$.

1969 års radioutredning, som lämnade sitt betänkande 1973, ville emellertid ga ännu längre i decentraliseringen av etermedieverksamheten i Sverige. Man förslog nämligen ett landstäckande system med lokalradiostationer. Dessa skulle genom lokal nyhetsförmedling, debatter om kommunala frăgor och samhällsinformativa program.ge en ortsanpassad information. Man betonade ocksa att enskilda medborgare, olika grupper och interessen skulle ges ökade möjligheter att komma till tals.

Förslaget om ett landstäckande system med lokalradiostationer fann gehör i flere politiska läger, och 1977 var systemet fullt utbyggt.

Behovet av en särskild kanal för utbildning och undervisning hade till stor del tillfredsställts $i$ och med att ett speciellt statligt organ, Kommittén för television 
och radio 1 utbildningen (TRU) 1967 hade inrättats för detta ändamå. 1978 gick TRU samman med Sveriges Radios utbildningsprogramenhet och bildade Sveriges Utbildningsradio $\mathrm{AB}$ - ett fristáende dotterbolag till Sveriges Radio AB. Organisationer och folkrörelser hade dock ännu inte fátt möjlighet att komma till tals i etern.

Nästa utredning om den statliga etermediepolitiken, 1974 års radioutredning, lämnade sitt betänkande 1977. Denna utredning kom tillbaka till frågan om $s \mathrm{k}$ sårskild rundradio och ansåg att det på det lokala planet finns ett informationsbehov som inte kan tillgodeses av den allmänna rundradion. Utredarna uttalade sig allmänt positivt för en vidgad etableringsrätt för lokal programverksamhet i radio och TV, men ansåg att detta måste bli föremål för särskild utredning, kompletterad med törsöksverksamhet.

Remissinstanserna var huvudsakligen positiva till förslaget om en sådan försöksverksamhet och $\mathrm{I}$ den proposition som följde på radioutredningen föreslogs en sådan verksamhet komma till stånd under en begränsad tidsperiod. En parlamentariskt sammansatt utredning, som sedemera antog namnet Närradiokommittén, skulle ansvara för försöksverksamheten och utvärderingen av densamma.

\section{Nårradions organisation}

1 juni 1978 trädde den lag i kraft som gjorde det möjligt att sända s $k$ närradio och när-TV i Sverige fram to $m 30$ juni 1981. Lagen har senare ändrats så att dessa typer av sändningar far fortsätta to m 30 juni 1982.

Syftet med en särskild rundradio skulle, enligt 1974 ars radioutredning, vara att förbättra möjligheterna för föreningar och organisationer att kommunicera med medlemmar och andra interesserade. Sändningsrätten är i det nuvarande försöket begränsad till lokala sammanslutningar som utgör juridisk person och som bedriver ideell, politisk, facklig eller religiös verksamhet inom det område till vilket sändningen riktas. Detta utesluter riksorganisationer utan juridiskt självständig organisation på det lokala planet, exempelvis Svenska Arbetsgivareföreningen, Kommittén för mänskliga rättigheter i Sverige, Scientology-kyrkan i Sverige m.fl. Det utesluter ocks̊ enskilda individer och myndigheter, vilka enligt 1960 ås radioutrednings förslag skulle ha rätt att sända. I det förslag som nu lämnats av 
Närradiokommittén efter ungetär 18 månaders försöksverksamhet, föreslås att sändningstillstånd endast ges till "...sådan lokal sammanslutning som är juridisk person och som har till huvudsakligt syfte att främja ideella och fackliga ändamål. Sammanslutningen skall, om inte särskilda skäl föranleder annat, sedan minst ett år före ansökningsdagen bedriva verksamhet inom sãndningsområdet" (SOU 1981: 13 sid 1978).

Formuleringen "huvudsakligt syfte" skulle bla. utesluta konsumentkooperativa föreningar, vilka under försöksperioden har deltagit p\& flera orter. Definitionen tillater däremot att konsumentgillen deltar i verksamheten, eftersom de har till huvudsakligt syfte att främja konsumentfackliga ändamal. Tanken har varit att utesluta alla organisationer som bedriver ekonomisk verksamhet eller kan antas ha ekonomiskt interesse av att delta i närradioverksamheten.

För att fa sändningstillstånd krävs idag, utöver de formella krav som redan nämnts, att organisationen har utsett en ansvarig programutgivare med ställföreträdare.

Närradions lokala karaktär framgâr av att sändningarnas răckvidd är begränsad till $4-5 \mathrm{~km}$. Sändarnas effekt var från bôrjan |W ERP. Stockholms innerstad utgjorde ett undantag, eftersom mottagningsförhålandena där ansågs vara speciellt dåliga. Efter att de sändande sammanslutningarna på flera orter klagat på mottagningsförhallandena där ansågs vara speciellt dåliga. Efter att de sändande sammanslutningarna på flera orter klagat på mottagningsförhållandena höjdes effekten pa samtliga orter till 10 W ERP. Avsikten med denna höjning var inte att öka närradions räckvidd utan att förbättra hörbarheten inom det område inom vilket Televerket ursprungligen garanterade hörbarheten (4-5 km från săndarna). I praktiken har dock den radie inom vilken det är möjligt att höra närradiosändningar okat till ca $7 \mathrm{~km}$ i och med denna effektökning.

Av tabell 1 framgår vila orter som deltar i försöksverksamheten. Under hösten 1978 fick de tilltănkta sändningsgrupperna möjlighet att ange sitt intresse för deltagande i försöket. Frăn de orter som inkom med interesseanmälan valdes 15 ut som försöksområden för närradio på ett sådant sätt att man fick med olicka typer av organisationer, olika typer av orter ocht olika delar av landet. Som sextonde ort valdes en, frân vilken inte någon intresseanmälan hade inkommit. En av de utvalda orterna kom sedemera att ersättas av en annan, då någon verksamhet där aldrig kom igang. 
De föreningar som vill delta i försöksverksamheten inkommer till Närradiokommittén med önskemal om săndningstider. Närradiokommittén beslutade i ett inledningsskede att endast ansökningar om jämna 15-minutersperioder skulle behandlas. $\mathrm{P}$ a vissa orter har lokala närradioföreningar tagit pa sig ansvaret att samordna organisationernas önskemal som sändningstider innan ansőkningarna sänds in till Närradiokommittén. De deltagande sammanslutningarna tilldelas sändningstid med minst 15 minuter per vecka och dărutöver programtid enligt onnskemål. En sammanslutning som vill ha sändningstid var fjortonde dag eller mer sällan måste dela med en annan organisation. Under försöksverksamhetens gång har föreningarna möjlighet att ändra sändningstid efter kontakter med Närradiokommitténs kansil. 


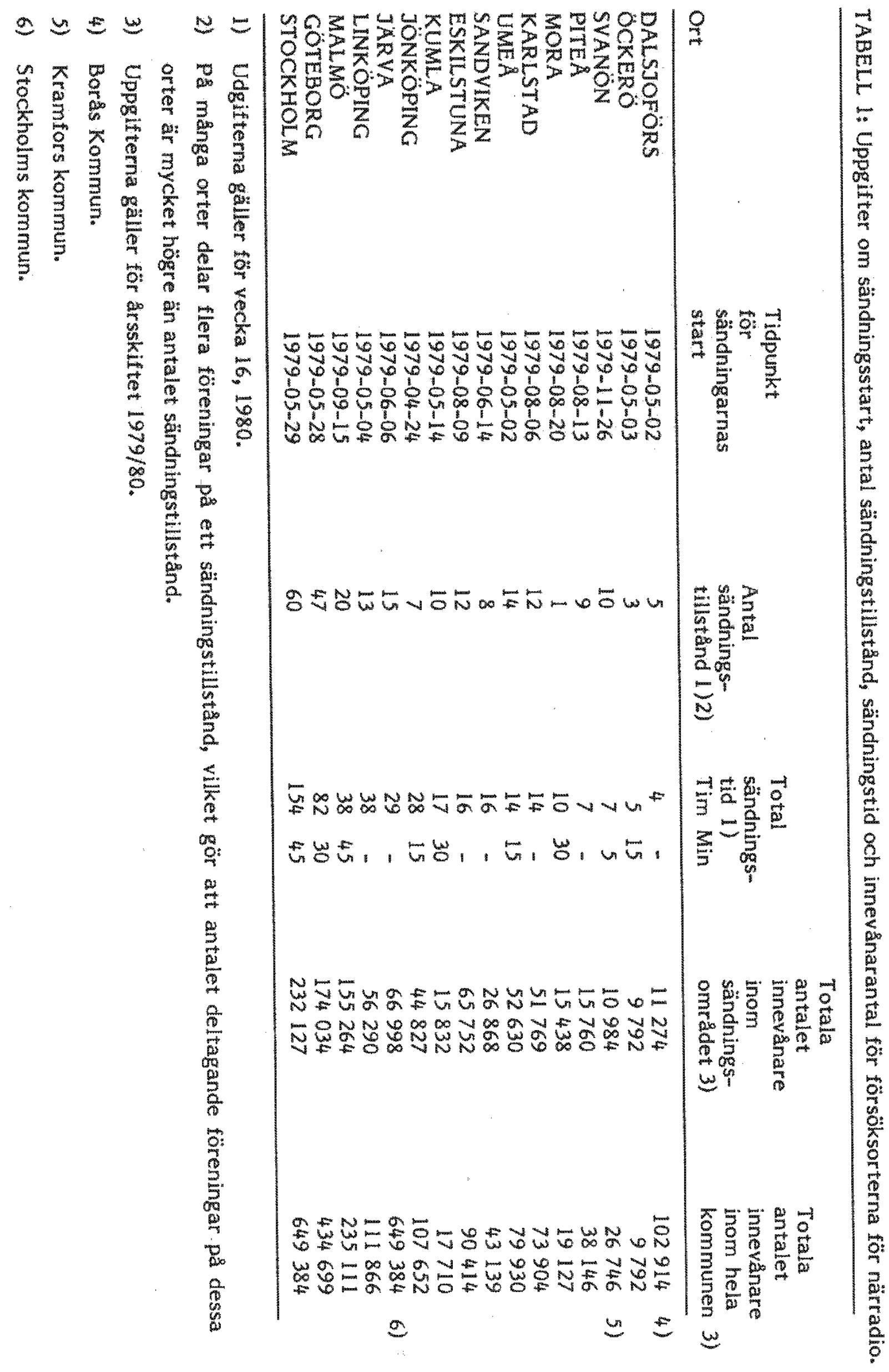


De deltagande sammanslutningarna producerar sina program till allra största delen självständigt. Program producerade centralt av någon riksorganisation tillhör undantagen. Endast två organisationer har mer regelbundet använt sig av detta förfaringssätt. Sammanslutningarna svarar själva för alla kostnader i samband med programproduktionen. Statliga medel har tillskjutits under försöksperioden för att finansiera Närradiokommitténs arbete, inkluderande bl.a. det vetenskapliga utvärderingsarbetet.

Någon förhandsgranskning av innehăllet i programmen förekommer inte. Med undantag av förbud mot kommersiell reklam och sponsring av program finns inga regler för hur verksamheten skall bedrivas. Radiolagen är inte tillämplig i det här fallet och organisationema har inte förbundit sig att följa några etiska regler, vilket journalister verksamma inom dagspress och etermedier i Sverige tvingas göra. Självfallet gäller allmän lag, men några specialregleringar, med undantag av vad som redan nämts, förekommer inte. Opinionsbildning i form av marknadstöring av idéer, asikter och vărderingar är självfallet tillåten, utan krav på opartiskhet.

Under försöksperioden har brott mot rådande regler behandlats av Närradiokommittén. I kommitténs betänkande föreslås denna uppgift läggas på den centrala närradiomyndighet, vars huvudsakliga uppgift annars föreslås vara att bevilja sändningstillstånd och fördela sändningstider.

Sammanfattningsvis kan vi konstatera att den nuvarande försöksverksamheten med närradio i Sverige bör följa nedanstående riktlinjer:

- sändningarnas räckvidd skall vara begränsad till $4-5 \mathrm{~km}$

- endast vissa typer av sammanslutningar som är verksamma inorn sändningsomr\&det skall f\& sändningstillstånd

- innehallet i programmen skall ha lokal karaktär

- ansvaret för varje sändning skall vila på en av den sändande organisationen utsedd person - programutgivaren

- de sändande organisationerna skall själva stå för alla kostnader förenade med verksamheten

- kommersiell reklam och sponsring av program är forbjuden.

Jämför man med 1960 ârs radiotredning, som alltsă var först med idén om $s k$ särskild rundradio, finner man flera skillnader, av vilka en del redan framhallits. Några krav på att săndningarna skall vara av lokal karaktär ställer inte 1960 års 
utredning. När det gäller innehållet menar utredningen att detta snarare bör vara speciellt än allmänt. Som exempel på allmän programverksamhet nämner man vanliga nyhetsprogram, musik, teater och allmänreportage. En annan skillnad är att den tidigare utredningen kunde tänka sig att ge myndigheterna sändningsrätt.

Försöksverksamheten med närradio kom igång under april 1979. Ungefär hälften av de deltagande orterna startade sina sändningar före sommaren det året. Resterande orter startade under hösten, den sista så sent som under november månad.

\section{Några resultat från nårradions försöksverksamhet}

Den vetenskapliga utvärderingen av närradioförsöket har genomförts i fyra delstudier, nämligen:

(1) En studie av allmänheten och närradions betydelse för enskilda individer,

(2) en studie av sammanslutningars interesse för närradio,

(3) en studie av lyssnandet på närradio och

(4) en innehållsanalytisk studie av närradions programutbud:

I slutet av denna artikel finns en förteckning över de forskningsrapporter som avlämnats.

\section{Deltagande organisationer}

De till antalet dominerande organisationstyperna i närradion är de religiösa och de politiska. När en lyssnarundersökning genomfördes under vecka 161980 var 26\% (64 av 243) av de deltagande föreningarna religiơsa och $19 \%$ (47) var politiska. De frireligiösa samfunden dominerar 1 den första gruppen och de borgerliga partierna 1 den andra.

Om man jämför sändningstiden, i stället för antal organisationer, finner man en ännu större dominans för de religiösa samfunden. $45 \%$ av sändningstiden utnyttjades den undersökta veckan av religiösa samfund, medan endast $6 \%$ av tiden användes av de politiska partierna.

Pa tre orter svarade de religiösa organisationerna för $90 \%$ eller mer av den totala 
sändningstiden. Pa en ort hade idrotts- och invandrarorganisationer en stor del av sändningstiden, medan andra interesseorganisationer svarade för större delen av săndningstiden på två andra orter.

Om man ser till programmens innehall kan i genomsnitt $42 \%$ av programmen klassificeras som religiösa. $\mathrm{Pa}$ de orter där de religiösa organisationerna dominerar sändningstiden förekommer också en större andel program med religiöst innehåll. $10 \%$ av programmen har en politisk inriktning och närmare hälften av programmen har varken religiös eller politisk inriktning. Från olika hall riktas kritik mot den religiösa dominansen. Aven de religiösa samfund som sänder närradio skulle gärna se att fler profana föreningar deltog i verksamheten, för att man därigenom skulle nå andra lyssnargrupper.

\section{Behovet av en lokal informationskanal}

Relativt många av allmänheten på de undersökta orterna var missnöjda med den information de hade tillgång till. Närmare hälften uppgav sig exempelvis vilja ha bättre information om kommunala frågor och drygt $40 \%$ ville veta mer om sin egen trakts historia och traditioner. P\& frågan om vad man helst skulle vilja höra i närradion uppgav också närmare $40 \%$ att de skulle vilja höra mer om kommunala angelägenheter och kommunal politik. Det finns alltså ett ganska utbrett informationsbehov, vilket skulle kunna tillfredsställas av ett medium inriktat på att förmedla lokal information.

Sammanslutningarnas motiv för att delta i försöket var, som väntat, en önskan att sprida information om egna idéer och det egna budskapet och att kunna förankra dessa hos allmänhet och medlemmar samt att skapa ett ökat engagemang i föreningslivet. De flesta religiösa organisationer hade angivit evangelisation som huvudsakligt syfte med att delta. Man kan alltså konstatera att det även från organisationernas sida finns ett stort intresse för och behov av ett nytt lokalt medium.

Man kan också notera att några organisationer angav att de deltar "för att andra är med" och utan att ha gjort någon egen förhandsbedömning.

De flesta av de organisationer som inte deltar i försöket motiverar detta med att de har för små ekonomiska och personella resurser (45\%). Aven för organisationer med en förhållandevis stor budget var detta det vanligaste skälet för att inte delta. Att sändningsradien är för liten angav 12\%. Man hänvisar inte till att något 
behov av en ny kanal inte existerar.

Bland de icke sändande föreningarna varierade uppfattningen om behovet av närradio betydligt. Generellt ansåg inte de stora organisationerna att de behövde närradio.

\section{Kunskap om och förväntningar på närradio}

Allmänhetens kunskap om närradion visade sig vid en undersökning före närradions start vara förvånansvärt stor. Hela $86 \%$ av allmänheten uppgav sig ha hört talas om närradion innan de fătt information om den genom undersökningen. Drygt en fjärdedel sade sig också känna till någon förening som skulle delta i försöksverk samheten.

Fờrväntningarna på närradion visade sig vara högt ställada bland allmänheten. Drygt halften av de svarande trodde att de skulle ha nytta av den information som närradion skulle komma att ge. Närmare $80 \%$ trodde att se skulle komma att lyssna på närradion.

De sändande sammanslutningarna hade också stora förväntningar på närradion, främst som ett aktivitetshöjande medel inom föreningsverksamheten. Man trodde at man genom närradion skulle få flere människor som besökte de aktiviteter som finns och att närradion skulle kunna användas för att värva nya medlemmar. Dessa positiva förväntningar fanns mest inom folkhögskolor och mindre etablerade organisationer, exempelvis vissa miljögrupper. Studieförbund och fackföreningar trodde inte att verksamheten inom föreningarna skulle påverkas av deltagandet $\mathrm{i}$ närradion. När de sändande föreningarna ett år efter närradiostarten tillfrågades om deras förväntningar på närradion hade infriats svarade $55 \%$ "ja".

Uppskattningen av hur stor del av allmänheten som skulle komma att lyssna på närradion varierade en del mellan de sändande och de icke sändande sammanslutningarna. Av de förra trodde ungefär hälften att andelen skulle ligga omkring 10\%. Aven bland de icke sändande föreningarna var dettá den vanligaste uppfatningen. Detta stämmer rätt väl med resultaten från lyssnarundersökningen, som visar att mellan $9 \%$ och $24 \%$ av allmänheten är regelbundna närradiolyssnare och att gennomsnittligt $15 \%$ är det. Av de regelbundna lyssnarna är ungefär en fjärdedel medlemmar i sändande föreningar. Av de icke sändande sammanslutningarna trodde dock hela $32 \%$ att enbart de sändande föreningarnas medlemmar skulle lyssna på närradion. Motsvarande andel bland de sändande sammanslut 
ningarna var betydeligt lägre, nämligen 7\%. Resterande andelar i de bägge kategorierna trodde att mer än $10 \%$ av allmänheten skulle lyssna.

Andelen som tror att närradion främst når de sändande organisationernas egna medlemmar är större i efterundersökningen såväl bland săndande som icke săndande sammanslutningar.

\section{Innehallet i näradioprogrammen}

Den totala sändningstiden för de 16 orterna en vecka på hösten 1979 skulle, enligt tillgängliga uppgifter, uppgå till ca 300 timmar. Under varen 1980 hade antalet timmar ókat till ca 480 . En innehallsanalys av en veckas program från hơsten 1979 och från en dag hösten 1980 har genomförts. Den första analysen har omfattat ca 200 timmar (396 program). Resterande tid utgörs dels av program som på grund av tekniska missöden inte blivit inspelade eller som spelats in men av något skäl inte kunnat avlyssnas, dels av sändningstid som inte uttnyttjats.

Vi försökte bedöma vad det huvudsakliga syftet med varje program var och fann att det vanligaste syftet tycktes vara att ge information. Det näst vanligaste syftet tycktes vara att forra fram sitt budskap. De ämnen som behandlades oftast var organisationernas verksamhet samt religion och trosfrågor.

De dominerande inslagen i programmen var "reportage och intervjuer", "kommentarer, information", samt "allmänt nyhetsmaterial, sportsresultat, evenemagstips". Man kan notera att det förekom inte heller i någon nämnvärd omfattning.

Det var vanligast att sända bandade program från en studio. Bara $9 \%$ av programmen utgjorde direktsändningar. Den vanligaste presentationsformen var uppläsning eller tal av en programledare, Dette förekom i över hälften av inslagen. Huvuddelen av programinslagen bestod av talade inslag. Endast i $15 \%$ av inslagen dominerade musiken. Av de enskilda orterna hade Stockholm den största andelen musikinslag.

En av försöksortema, Öckerö, avviker markant frăn övriga försöksrområden bl.a. vad gäler innehallet 1 programmen. Ungefär tre fjärdedelar av programinslagen där belyser saker som har lokal anknytning till kommunen. Musikutbudet är litet i jämförelse med programmen pa övriga närradiosăndande orter. Totalt utgörs endast $12 \%$ av den totala sändningstiden av musik. Större delen av denna musik är 
egentillverkad och spelas av lokala musiker. Öckerösändaren har den näst kortaste sändningstiden av alla närradiosändarna, men tycks trots detta ha fått ett starkt gehör hos lyssnarna. Öckerös speciella karaktäristika, exempelvis ett särpräglat geografiskt läge, små föreningar, ett aktivt lokalsamhälle, problem med kommunikationen mellan de i kommunen indgående örana och avsaknad av lokala medier, tycks sätta sin prägel på hela närradioförsöket i kommunen. Närradion fyller en funktion som "lokal" lokalradio.

Avgifter till upphovsrättsorganisationer infördes efter 1 juli 1980. Det kunde vara intressant att se om detta havde paverkat musikutbudet i närradion. En jämförelse mellan musikutbudet 1979 och 1980 gjordes genom en specialanalys av utbudet en torsdag hösten 1979 och en torsdag hosten 1980. Hittills finns resultat framtaget endast från två av försöksorterna. Såvăl 1979 som 1980 var musikutbudet större på den ena orten. Pa den orten var musikutbudet något mindre den analyserade dagen 1980 än 1979, nämligen $50 \%$ mot 60\%. P\& den andra orten var musikutbudet ungefär lika stort båda dagarna, nämligen 40\%. Att andelen musik är så pass hög beror på att de få inslag, i vilka musiken dominerar, i allmänhet är mycket längre ân övriga inslag.

Pa en av orterna dominerade analysdagen 1979 den utländska musiken starkt, medan det 1980 var ett lika stort utbud av "rikssvensk musik" som utländsk. P\& den andra orten dominerade bägge analysdagarna kategorin "rikssvensk musik". Den lokala musiken hade en relativt undanskymd plats. $\mathrm{p} \&$ den ena orten utgjorde den $2 \%$ av det totala musikutbudet 1979 och $5 \% 1980$. Pa den andra orten fanns 1979 ingen lokal musik alls och 1980 utgjortde den lokala musiken där $2 \%$ av det totala musikutbudet. På bägge orterna kan man konstatera att bakgrundsmusiken har minskat kraftigt i omfattning från 1979 till 1980. Det är svårt att med de nu tillgängliga uppgifterna dra några slutsatser om hur afgivterna till upphovsrättsorganisationerna paverkat utbudet i närradion.

\section{Närradions lokala förankring}

Enligt den ursprungliga tanken med närradio skall verkșamheten vara av lokal karaktär. Med detta kan man avse både att produktionen av närradioprogram skall ske lokalt och att distributionen skall begrănsas geografiskt. Man kan också avse att programinnehallet skall ha vissa speciella karaktäristika, exempelvis vara av lokal karaktär. 
Hur viktigt anser då allmänheten att det är, att närradioprogrammen har lokal karaktärr? I förundersökningen ansåg närmare $70 \%$ att det är mycket viktigt att närradions program behandlar lokala frågor. $43 \%$ ansåg ocksa att det är mycket viktigt att personer som medverkar i programmen har lokal anknytning och $48 \%$ att det är mycket viktigt att det finns möjligheter att påverka programmen. Det senare förutsätter nästan en lokal produktion. Man är dock själv inte i någon större utsträckning beredd att vare sig medverka eller påverka programmen på annat sätt.

Av innehållsanalysen framgår att en stor del av programinslagen, $41 \%$, saknade geografisk anknytning. Det gällde exempelvis de flesta religiösa program. Av de programinslag som hade nagon geografisk anknytning hade dock $66 \%$ en lokal sådan.

Program producerade centralt, exempelvis inom en riksorganisation, tycks inte förekomma i någon nämnvärd utsträckning. I förundersökningen av föreningarna sade sig en femtedel av de föreningar som ingick I en riksorganisation ha för avsikt att utnyttja material från denna. Trots att över $80 \%$ av de deltagande organisationerna ingår i en riksorganisation uppgav endast 25 av de totalt 200 undersökta sammanslutningarna att de fătt material frăn sin huvudorganisation. En tredjedel av dessa hade anvănt sig av materialet. Dette antyder att problemet med centralproducerade program som distribueras till flera närradiostationer tycks vara avgränsat till ett fåtal sammanslutningar.

\section{Närradio vs andra massemedier}

Relationerna mellan närradion och lokalradion och den lokala dagspressen har varit föremål för diskussion ända sedan det blev aktuellt att sända närradion. Man frăgar sig vad närradion kan ge föreningslivet som inte de andra lokala medierna kan ge; $86 \%$ av de sändande föreningarna ansåg att närradion kunde fylla en funktion som de övriga medierna inte kan fylla. Vad förväntar man sig da av närradion som inte lokalradio och lokalpress klarar av? Sammanslutningarna uttryckte en viss besvikelse över lokalpressens och lokalradions ringa intresse för och vilja att låta små organisationer komma till tals. Man trodde att närradion skulle vara annorlunda i detta avseende och att bl.a. bevakningen av lokala hăndelser $\mathrm{I}$ och med närradions införande skulle förbättras. Eftersom närradion medger stor frihet såg man också möjligheten att sätta större personlig prägel på 
programmen än vad som är vanligt i exempelvis lokalradion.

En del av de icke sändande organisationerna ansåg dock att det finns bättre alternativ än närradion om man vill låta små organisationer komma til tals. Man borde i stället satsa på lokalradion eller utnyttja Sveriges Radio eller pressen som informationskanal i större utsträckning. Sist men inte minst borde man öka de personliga kontakterna mellan medlemmar och allmänhet. Dessa recept lämnade $68 \%$ av de icke săndande organisationerna.

\section{Malgrupper ach lyssnargrupper}

Vilka målgrupper vill föreningarna nå via närradion? De flesta sändande föreningar, ca $60 \%$, ville i första hand na allmänheten. Att man ville nå de egna medlemmarna angav en sa pass liten del som 16\%, vilket torde visa att man främst ser närradion som en möjlighet att sprida information till större kretsar. Dock sade sig fackföreningar och invandrarorganisationer främst vilja nå ut till sina medlemmar.

Aven när föreningarna fick ange mălgrupp för enskilda program var allmänheten den vanligaste målgruppen (22\%). $7 \%$ av programmen uppgavs rikta sïg till såväl organisationsmedlemmar som allmänhet. Endast $9 \%$ uppgavs enbart vara avsedda för de egna medlemmarna. Ovriga program hade någon specifik mågrupp, som exempelvis invandrare, barn, studenter, pensionärer $\mathrm{m.m}$.

Når föreningarna da ut med sin information och, i sa fall, till vilka grupper? En lyssnarundersökning visar att andelen regelbundna lyssnare, dvs de som lyssnar minst en gång i veckan, varierar mellan de olika orterna från $9 \%$ upp till $24 \%$. Genomsnittligt lyssnar $15 \%$ av befolkningen pa de undersökta orterna regelbundet på närradio. Enskilda program hörs i genomsnitt av ca $1-2 \%$ av de potentiella lyssnarna.

Lyssnandet bland allmänheten ăr betydeligt lägre än bland dem som har anknytning till någon förening som deltar i försöket. Ett exempel från Eskilstuna är Filadelfiaförsamlingens medlemmar av vilka $78 \%$ kan sägas vara regelbundna lyssnare, medan motsvarande andel för allmänheten i Eskilstuna är 14\%. Flladelflaförsamlingen svarade under den undersökta perioden för $53 \%$ av programutbudet i Eskilstuna nårradio. 
Lyssnarstrukturen, när det gäller variablerna kön, utblidning och sysselsättning, avviker inte från det mönster som erhălls vid studier av riksradiolyssnandet. Däremot kan vi notera en avvikelse för åldersvariabeln. Närradion når förhållandevis fler i yngre ålderskategorier än vad riksradion gör. Dette gäller framför allt i Stockholm och Järva. Det generella mönstret är att de äldsta och yngsta lyssnar mest på närradio. De viktigaste vaiablerna för att förklara skillnader i närradiolyssnande tycks vara ålder, graden av föreningsaktivitet och lokal identifikation. Det senare är mest påtagligt på de mindre orterna, exempelvis Ockerö, där den mest trogne lyssnaren visar sig vara äldre, föreningsaktiv och uppfödd inom kommunen.

\section{Inställningen till närradio}

I förundersökningen tillfrågades föreningarna om de ansåg att det var bra att man startade försök med närradio. Såäl bland de sammanslutningar som deltog $\mathrm{i}$ försöket, som bland de som inte hade för avsikt att göra det, fanns det en majoritet som ansåg att det var bra att starta försök med närradio. Mest positiva (86\%) var givetvis de föreningar som deltog. Bland de föreningar som inte deltog hade ungefär tre fjärdedelar en positiv inställning till att försöket genomfördes. Mest positiva var religiösa församlingar, folkhögskolor och små organisationer. Minst positiva var fackföreningar.

Efter ca ett års verksamhet ansåg många sändande sammanslutningar (71\%) att närradioen påverkat deras organisations aktivitet. Vad som oftast nämndes i sammanhanget var att man upplevede sig ha fått bättre kontakt med allmänheten, att man fått nya medlemmar och bättre kontakt med sina gamla medlemmar. I övrigt nämnde föreningsrepresentanterna som positiva effekter att flera människor kom till föreningsmötena, att man hade fått en bredare verksamhet och, rent allmänt, att den egna sammanslutningen hade fått mer uppmärksamhet.

En dryg fjärdedel av sammanslutningarna ansåg dock att närradion inte hade haft någon inverkan på föreningsaktiviteten. Av de icke sändande föreningarna var det 96\% som inte trodde på någon ökad aktivitet på grund av närradio.

Generellt verkar de sändande sammanslutningarna nöjda med närradioverksamheten. Närmare $80 \%$ anser att närradion behövs och $82 \%$ anser att närradion bör permanentas. Något sådant stöd för närradion finns inte bland de icke sändande sammanslutningarna. Motsvarande andelar för dessa är $17 \%$ och $24 \%$. 
De sammanslutningar som förefaller vara mest nöjda med närradioverksamheten är invandrarorganisationerna och de religiösa samfunden. Studieförbunden och de politiska partierna förefaller minst nöjda med verksamheten.

\section{Sammanslutningamas kostnader för närradioverksambeten}

De kostnadsuppgifter som lämnas nedan gäller de kostnader som de deltagande sammanslutningarna uppger sig ha haft från närradions start till och med tidpunkten för undersökningens genomförande, dvs maj-juni 1980. I genomsnitt rör det sig om kostnader under ett knappt verksamhetsår. Kostnaderna är i undersökningen uppdelade på driftskostnader - bestående av hyra för studio och kostnader för personal och administration - och kapitalkostnader - bestående av kostnader för investeringar i studio och teknisk utrustning.

De sammanlagda driftskostnaderna uppgår till i genomsnitt $11.500 \mathrm{kr}$ för de 138 organisationer som uppger sig ha haft kostnader av detta slag. De genomsnittliga kapitalkostnaderna har uppgatt till $16.500 \mathrm{kr}$ för de 132 sammanslutningar som uppger sig ha haft kostnader av detta slag.

Förklaringen till att vissa föreningar har uppgett att de inte sjălva har haft några driftskostnader eller att de inte har haft några investeringskostnader är sannolikt att de har lånat studio och teknisk utrustning och liknande från någon moder- eller systerorganisation eller från medlemmar eller att man redan tidigare hade studio och studioutrustning, varför man inte belastats med kostnader för detta. Vissa avgifter kan ha betalats direkt av enskilda medlemmar eller av någon närstaende organisation. Ytterligare en förklaring till att man uppger sig inte ha haft nagra driftskostnader kan vara att man har haft svärigheter att skilja dessa från investeringskostnaderna eller att man helt enkelt inte brytt sig orn att göra det i redovisningen till under sökningen.

Totalt uppger sig de 179 sammanslutningar som svarat pa kostnadsfrågorna i undersökningen ha lagt ned runt 3,8 Mkr på försöksverksamheten. Genomsnittlig kostnad per sammanslutning blir för dessa ca $21.000 \mathrm{kr}$.

De som har högra kostnader för närradioverksamheten än andra är givetvis i först hand de föreningar som har ett stor programutbud. Som redan nämnts gäller dette framför all de religiösa samfunden. Av 13. sammanslutningar som har mer än 
$40.000 \mathrm{kr}$ i driftskostnader är 8 religiösa församlingar och av 14 organisationer med en sammanlagd investeringskostnad överstigande $40.000 \mathrm{kr}$ är likaledes 8 religiösa. Mot de sammanslutningar som uppger sig klara verksamheten utan några som helst egna medel kan exempelvis ställas en frireligiös sammanslutning, som med en totalkostnad pa $215.000 \mathrm{kr}$ under den första verksamhetsperioden, toppar kostnadsstatistiken. 145.000 av denna summa utgör investeringar i stuio och teknisk utrustning och $70.000 \mathrm{kr}$ utgồr driftskostnader.

Närradioverksamheten är givetvis förknippad med vissa, såväl fasta som rörliga, kostnader, som de deltagande sammanslutningarna inte kan komma ifrån. Nagra sådana är, förutom de rena investeringskostnaderna, kostnader för hyra av săndare tillhandahållen av televerket, kostnader för att hålla referensband under en period av minst sex månader från săndningstillfället, kostnader i samband med avgifter till upphovsrättsorganisationer och, i vissa fall, kostnader till lokal närradioförening.

Under försöksperioden har hyra för săndaren uppgått till $7.800 \mathrm{kr}$ per försöksort och år. En debiteringsavgift pa $200 \mathrm{kr}$ tillkommer. Hyreskostnaden är trån televerkets sida fast, vilket innebär att kostnaderna per tidsenhet räknat, är lägre p\& orter med längre sändningstid än på orter med kortare sändningstid. I Stockholm, som har den längsta sändningstiden, rör det sig om 25 öre per sändningskvart, medan motsvarande kostnad i exempelvis Eskilstuna är 2:30 för samma tid. En förening som sänder 15 minuter varje dag får 1 Stockholm betala ca $90 \mathrm{kr}$ per ar för sändarhyra och i Eskilstuna ca $800 \mathrm{kr}$. Till detta kommer eventuell hyra för săndningskabel till egen studio (2000 kr per kalenderăr).

Kostnaderna för hallande av referensband är givetvis helt beroende av hur mycket man sänder. Dock rơr det sig inte om några stơrre belopp. 15 minuters săndning per dag innebär att föreningen făr räkna med att ha ca $400 \mathrm{kr}$ investerat $\mathrm{i}$ referensband. Referensbanden skall sparas i sex månader efter sändning.

Fram till och med juni 1980 var sändningarna i närradio befriade från avgifter till upphovsrättsorganisationer. Sedan avtal träffats under hösten 1980 tas en avgift ut som är beroende av sändarortens storlek och antalet sända musiktimmar. Vissa rabatter kan erhallas om föreningarna går samman om gemensam betalning till STIM/IFPI. Om man utgår från att $40 \%$ är musik kommer årsavgiften för en förening i Stockholm att bli ca. $7.500 \mathrm{kr}$ (fortfarande förutsatt att man sänder 15 minuter varje dag), om man bortser från eventuella rabatter, och för en förening $\mathrm{i}$ 
Eksilstuna ca $2.600 \mathrm{kr}$.

Några avgifter för sändningstillstånd har inte förekommit under försöksperioden. I en eventuell framtida permanent verksamhet făr man räkna med någon form av sådan avgift. På de orter där en lokal närradioförening skapats har detta medfört uttag av den relativt blygsam avgift om några hundralappar per år och deltagande organsiation.

\section{Framtida organisationsform}

Majoriteten av de sändande föreningarna, 60\%, stödjer den nuvarnade organisatoriska formen för verksamheten. Det finns emellertid en stor grupp (21\%) som kan tänka sig alternativa modeller. Ingen av de föreslagna modellerna samlar dock någon större andel förespråkare. Det är exempelvis bara sex föreningar (3\%) som föreslår ett samarbete med lokalradion.

Av de icke deltaganda föreningarna är det $36 \%$, som, om närradion permanentas, anser att den nuvarande organisatoriska modellen är acceptabel. Resten har antingen inte svarat på frågan (49\%) eller förslagit andra former (15\%). Några förslag till andra organisatiorisk former är exempelvis att närradion inordnas 1 Sveriges Radios normala programverksamhet, att det på lokal niv̊̊ bildas lokalråd för närradion med representanter för samtliga folkrörelser, att medverkan görs kostnadsfri för ideella sammanslutningar och att de små föreningarna ges större möjligheter än i dag att delta.

Föreningsrepresentanternas upplatningar om den framtida organisationsformen för närradioverksamheten kan jamföras med lyssnarnas uppfattning. I genomsnitt menar $65 \%$ av de som lyssnar på närradio regelbundet, dvs minst en gång i veckan, att närradion skall vara kvar i sin nuvarande form. $21 \%$ vill ha närradio. Ovriga har inte svarat på frågan eller saknar åsikt. Stödet för den nuvarande formen varierar mellan försöksorterna. P\& orter där de religiösa organisationerna dominerar finns bland regelbundna lyssnare ett starkara stöd för nuvarande organisationsform än på andre orter. 


\section{Några avslutande kommentarer}

Redan tidigt mötte förslaget om närradio/när-TV en hel del kritik. Kritiken kom främst från representanter för det socialdemokratiska partiet och för vänsterpartiet kommunisterna. Centerpartisterna höll sig avvaktande, medan representanter för moderata samlingspartiet och, framför allt, för folkpartiet har arbetat mycket för idén med närmedier. Av de fem riksdagspartierna i Sverige har två, folkepartiet och moderaterna, antagit ett specifikt mediepolitisk program. I folkpartiets medieprogram sägs klart att Sverige bör få närradio. Detta hade man formulerat innan försöksverksamheten startat. I moderaternas medieprogram är närradiofrågan inte så central. I detta program betonas generellt viljan att arbeta för en friare etermedieverksamhet i Sverige, där närradio och när-TV är några av flera nya element. Många kritiker har ansett att närradion öppnar vägen för en helt fri och kommersiell radio. Huruvida den uppluckring av radiomonopolet som sker vid en eventuell permanentning av den nuvarande försöksverksamheten med närradio leder fram till konsekvenser av detta slag, torde dock vara svårt att uttala sig om.

Något som framfördes mot förslaget om försök med närradio var att dessa försök kunde komma att hämma lokalradions just påbörjade verksamhet. Dessa farhågor framfördes främst av socialdemokraterna som kan sägas vara ivriga förespråkare för såväl försök med föreningssändningar i lokalradion som för lokalradion som sådan. Det är idag svårt att avgöra hur pass relevant denna invändning mot närradion är. De resultat som vi hittills fått fram i våra undersökningar pekar inte på att det skulle föreligga något direkt konkurrensförhăllande mellan närradion och lokalradion ur lyssnarsynpunkt. Närradiolyssnandet inkräktar inte på några andra medieaktiviteter. De som är regelbundna lyssnare på närradio är också regelbundna lyssnare på lokalradio och riksradio. Undersökningarna gjordes dock relativt kort tid efter närradions start, vilket gör att förhållandena kan ha kan ha förändrats sedan dess. Ur ekonomisk synvinkel är närradion i sin nuvarande utformning heller inte något hot mot övriga kanaler, eftersom de närradiosändande sammanslutningarna själva står för alla kostnader.

Klart är att det i några fall och på några försöksorter har förekommit situationer av konkurrenskaraktär mellan närradio och lokalradio. Exempelvis har kommunfullmäktiges sammanträden och andra större intresseväckande aktiviteter inom en kommun bevakats av både närradion och lokalradion på platsen. Om detta verkar hämmande på lokalradions utveckling är dock tveksamt. Det finns skäl att anta att närradion i viss mån stimulerat lokalradions utveckling. Min personliga uppfattning, som jag idag inte har stöd för i någon undersökning, är att 
lokalradions intresse för fơreningar och folkrörelser har ökat väsentligt sedan närradions start. Detta skulle i så fall ga helt emot de farhågor som vissa närradiokritiker hyste inledningsvis. Flera lokalradiostationer har dragit igång satsningar, där syftet har varit att ge de lokala organisationerna mojlligheter att na ut till sina medlemmar och till potentiella medlemmar genom lokalradion. Om det föreligger ett klart orsakssamband mellan närradions tillkomst och lokalradions satsning på föreningar (och allmänhet) låter jag dock vara osagt. Denna utveckling, om den nu kan beläggas, kanske hade skett alldeles oavsett närradions start och kan $\mathrm{i}$ sa fall ses som ett steg i en mer allmän strävan att demokratisera medierna eller att föra medierna närmare folket.

I propositionen om närradio sägs att nagot konkurrensförhållande mellan närradio och lokalradio knappast kan komma att uppsta, eftersom närradion skall bygga på frivilliga insatser och använda billig utrustning till skillnad från lokalradion, som drivs mer professionellt i dessa avseenden. Rent innehålsmässigt skall man koncentrera sig på olika områden.

Vid en studie av allmänheten som gjordes p\& tre försöksorter för närradion kunde vi konstatera att närradions roll för lyssnarna varierade mycket mellan orterna. I Stockholm, den största närradioorten med ett markant inslag av populärmusik, fungerade närradion uppenbarligen som en musiktapet och som ersâttning för andra radiokanaler med musik, medan den på de båda andra orterna mer hade rollen av en informationskanal, vilken man ofta lyssnade pa utan att göra andra saker samtidigt. Lyssnandet utgjorde där, i större utsträckning än vad som är vanligt för radiolyssnande, en primäraktivitet.

Närradioförsőket har kritiserats för att den organisatoriska uppläggningen har varit alltför ensidig. Krav har rests på att åven försök med föreningsdeltagande i lokalradion skulle genomföras. Under vårriksdagen 1980 lade ett antal centerpartistiska riksdagsmän fram en motion om att flera alternativa produktions- och distributionsformer än de som förekommer inom närradioförsöket borde prövas innan slutlig ställning tas till närradion och innan en ny etermedieform permanentas. Motionen vann riksdagens gllande och i februari 1981 påbörjades en ettårig försöksverksamhet i Angelholm och Ljusdal, där såväl olika organisationer som enskilda individer erbjöds medverka i lokalradion. Sändningarna i Angelholm tàcker tre kommuner och sändningarna i Ljusdal täcker en kommun, och Sveriges Lokalradio AB står för kostnaderna och ställer professionellt folk till de săndandes fơrfogande. 
En första utvärdering av lokalradions försöksverksamhet gjordes några månader efter starten. P\& samma sät som de föreningar som deltar i närradioförsöket vill fortsätta med detta, är de föreningar som deltar i lokalradions försök beredda att stödja denna form för organisationsdeltagande $i$ etermedierna. En slutsats man kan dra av detta är att sammanslutningar i allmänhet har ett mycket stort behov av och intresse for att utnyttja radion i informations- och kommunikationssammanhang. En del data från utvärderingen av lokalradioförsöket antyder att närradioförsökets organisatoriska form inte är den rätta. De tillfrågade sammanslutningarna vill exempelvís inte sända så ofta som varje vecka och de upplever heller inte något större behov av fast sändningstid.

Det har befarats att närradion endast skulle kunna utnyttjas av stora och ekonomiskt starka organisationer och att reklam och andra kommersiella intressen skulle $1 a$ utrymme $\mathrm{i}$ etern, eftersom kostnaderna förenade med sändningarna skulle bli stora. Den verksamhet som hittills har bedrivits ger emellertid ingen grund fờ dessa farhågor. Vi har hittat många exempel på att det har varit möjligt att sända närradio till mycket ringa kostnader. Overträdelser av reklamförbudet har varit förhallandevis fa och obetydliga. De ekonomiska förutsättningarna för de deltagande organisationema har dock hittills varit relativt gynnsamma, eftersom bl.a. ingen avgift för spelad musik har behövt erläggas till upphovsrättsorganisationema för det första verksamhetsaret. Inte heller har de sändande organisationerna behôvt betala någon avgift för sändningstillstånd eller någon annan avgift till någon central myndighet.

De ekonomiska förutsättningarna kan emellertid komma att förändras I framtiden. Om finansieringen av en framtida central myndighet för närradioverksamheten lăggs p\& de enskilda sammanslutningarna p̊̊ så sätt att full kostnadstäckning erhalls, kommer avgiften fơr att sända närradio att bli så hög, att en del sammanslutningar inte kommer att ha rad att delta i verksamheten.

Trots att avgifterna till upphovsrättsorganisationerna nu har börjat betalas, har eventuella effekter av detta semnolikt ännu inte hunnit sla igenom. Man kan därför inte med någon săkerhet uttala sig om hur dessa avgifter kommer att påverka vilka föreningar som i framtiden kommer att sända och vad de kommer att sända. Alla avgifter slår naturligtvis hărdare mot små organisationer, dvs organisationer med förhållandevis få medlemmar och/eller liten budget, ân mot stora. Samtidigt är förutsăttningarna för att samla in medel för en verksamhet av det här slaget bättre inom en stor organisation än inom en liten. Hăr har de religiösa samfunden 
vissa fördelar. Många av de religiösa samfunden finansierar sin närradioverksamhet helt eller till stora delar genom kollekt. En annan fördel som de stora föreningarna har, är att de har större möjligheter att inom de egna leden finna för närradioverksamheten lämpeliga personer, som kanske på grund av sitt medlemskab och allmänna intresse är beredda att gratis sköta föreningens närradioverksamhet.

En annan invändning mot närradion är att den aldrig kan byggas ut till att nå alla, eller så gott som alla, innevånare i Sverige. Närradion var i sin urspungliga form, med en sändareeffekt p̊̊ ca 1 W ERP, en utpräglad tätortsradio. Med den förhöjda effekten har självfallet andelen potentiella lyssnare ökat. Enligt de beräkningar som gjorts av Närradiokommittén, skulle det vara frekvensmässigt möjligt att förse ca $70 \%$ av Sveriges befolkning med närradiosändningar. Ca. $30 \%$ av befolkningen kommer emellertid aldrig att fa möjlighett att nas av sina eventuella föreningars, organisationer, kyrkors eller skolors budskap via närradion. Det är naturligtvis svårt att veta i vilka termer man skall diskutera detta faktum, Går dessa människor miste om kulturell bildning, halkar de efter andra grupper i ekonomiskt avseende därför att de inte får samma information som dessa, får de sämre kunskaper om samhället och hur detta fungerar genom att de inte får ta del av närradioutbudet, ökar kunskapsklyftorna generellt mellan de grupper som har möjlighet att lyssna och de som inte har det? Utrymmet medger inte att jag här går närmare in på dessa intressanta spörgsmål, men jeg hoppas att få möjlighet att aterkomma till dessa vid ett senare tillfälle. 


\section{Referenser}

\section{Rapporter frân närradioundersokningen:}

- "Projektplan för utvărdering av försöksverksamheten med närradio" PM 1979. 10-02. Lowe Hedman, Sociologiska institutionen, Uppsala universitet.

- "Några preliminåra data från närradions förmätning." PM 1980-03-05. Lowe Hedman, Sociologiska institutionen, Uppsala universiet. Denna PM har senare ersatts av rapporten "Inför närradions start - förhandskunskaper, förväntningar $m$ bland allmänheten inför startandet av en ny informationskanal." Lowe Hedman, 'Sociologiska institutionen, Uppsala universitet. Februari 1981.

- "Närradion - inför starten." Ewa Bertling och Ingvar Tysell, Högskolan i Ostersund. November 1980.

- "Innehållsanalys av närradiosändningar i Linköping och Umea." PM 1980-12-08. Karin Wengelin, Sociologiska institutionen, Uppsala universitet.

- "Innehallet i närradioprogrammen. "Karin Wengelin, Sociologiska institutionen, Uppsala universitet. Februari 1981.

- "Närradion under konflikten på arbetsmarknaden." PM 1980-06-02. Kersten Wernberg, Sociologiska institutionen, Uppsala universitet.

- "Närradion - efterundersökningen." Version 2. Per-Åke Nilsson, Högskolan 1 Ostersund. November 1980.

- "Uppfattningar om närradion hos i försöket icke deltagande sammanslutningar." Lars-Erik Wolvén, Högskolan i Ostersund. December 1980.

- "Nărradion på Ockerö - en första redovisning av publikstudien." PM 1980-02-28. Svante Karlsson och Lennart Weibull, Statsvetenskapliga institutionen, Göteborgs universitet.

- "Ockerö närradio $1979 / 80$ - en studie av organisation, innehall och publik." Svante Karlsson. Uppsats för C-kursen i statsvetenskap, Göteborgs universitet, ht 1980. 


\section{Ovrigt material}

Hedman, L (1980), Närradion och dess lyssnare. DsU 1980:14 Liber Förlag* Stockholm.

Hedman, L, red. (1981), Utvärdering av nărradion. DsU 1981: 1. Liber Förlag. Stockholm.

Hedman, L (1981), Lokala etermedier - tillkomst och funktion I Gustafsson, K E (red.), Kommunikationspolitik och kommunikationsforskning. Rapport från ett symposium anordnat av massmedieseminariet ved Göteborgs universitet och Föreningen Svenska Masskommunikationsforskare 23-25 april 1980. Sid 111-138.

Proposition 1966:136.

Proposition 1977/78: 91 .

SOU 1965:20, Radions och televisonens framtid i Sverige

SOU 1973:8, Radio i utveckling.

SOU 1975:28, Program för 1 jud och bild I utvecklingen.

SOU 1977:19, Radio och TV 1978-1985.

SOU 1981:13, Närradio. 


\section{FRA KABLER TL FREKVENSER?}

\section{Af Ellen $\varnothing$. Andersen og Helle Baag .}

De engelske "community radios" har, efter at have sendt via tv-kabler i fem ar, nu i samlet flok meldt sig som tredie spiller i kampen om den britiske ater mod BBC og $\mathrm{BA}$, der kontrollerer Irekvenserne i øjeblikket.

Udviklingen af lokalradioer i England begyndte allerede i midten af tresserne, da BBC med støtte fra Labour-regeringen oprettede et to-årigt forsфg med ni lokale radiostationer. Fors $\emptyset$ get var en succes, og der var planer om flere lokalradioer, da Labour mistede regeringsmagten til de konservative 1 1970. De konservative prioriterede private, kommercielle radioer hфjere og gav i deres fireårige regeringsperiode 19 Independent Local Radios (ILR), tilladelse til at sende 1 teren. Hermed var BBC's radiomonopol brudt (tv-monopolet r $r g$ allerede 1 1954). ILRstationerne, hvis overordnede organisation er IBA, Independent Broadcasting Authority, bredte sig hurtigt over hele landet og man etablerede en struktur, hvor BBC og IBA havde henholdsvis 20 og 19 lokalradioer. I 1978 nedsatte Labourregeringen en arbejdsgruppe, der skulle skabe en falles udbygningsplan for $\mathrm{BBC}$ og IBA. Gruppen udsendte en rapport, som foreslog 18 nye stationer - ni til hver af de to selskaber. Men da de konservative igen kom til magten, fik ILR-stationerne frit $16 \mathrm{~b}$ og har for langst overhalet det mindre pengestarke BBC: Alene 11981 starter otte nye kommercielle radiostationer i England. En af dem, Essex Radio, vil dakke Basildon, hvis kabel-radio denne artikel bl.a. behandler.

BBC financieres af licens-penge. ILR-stationerne er aktieselskaber, hvis aktier for det meste ejes af lokale forretningsfolk og i mindre grad af aviskeder og andre kommunikationsselskaber. De kommercielle lokalradioer financieres af reklamer og mange af dem giver et paent overskud.

Indholdsmassigt adskiller BBC's og ILR's programmer sig ved, at de kommercielle radiostationer bringer betydelig mere musik og dermed betydelig faerre taleprogrammer end BBC. ILR-stationerne blander reklamer, information, nyheder, forbrugerrad, job-tips etc. sammen, afbrudt af "middle of the road"-musik. $\mathrm{BBC}$ sender flere egentlige udsendelser, $\mathrm{fx}$ diskussions- og telefonprogrammer. 